\title{
JOSÉ LUÍS JOBIM
}

José Luís Jobim de Salles Fonseca, aliás, Jobim, simplesmente, para todos os efeitos de identificação no espaço acadêmico, em especial no das Letras. Se buscarmos um análogo para as dimensôes de sua personalidade, na alternativa entre o extenso nome completo e sua versão minimalista, é na plenitude daquele que o encontraremos, e não na redução desta. Pois Jobim não é um, são vários.

Há, em primeiro lugar, o professor, dedicado ao ensino das matérias de sua eleição, no Brasil e no exterior. No magistério, fez carreira diversificada, iniciando-se nos níveis fundamental e médio, até concentrar-se no grau de sua preferência, o universitário, em que há muito atua na graduação e na pós-graduação. Lecionou no venerável Colégio Pedro II (onde, por sinal, foi aluno) e, depois, na Universidade Federal Fluminense (UFF) e na Universidade do Estado do Rio de Janeiro (UERJ), nas quais se tornou, por concurso público, professor titular de teoria da literatura.

A dimensão do docente, por sua vez, se compõe com outra, a do pesquisador. Assim, dos estudos sistemáticos das questóes de sua especialidade, lastro constante de suas aulas e cursos, vem resultando extensa produção intelectual, notável tanto pela abrangência, quanto pela qualidade, em que se contam conferências, palestras, publicaçóes. Entre estas, além de inúmeros ensaios em periódicos especializados e livros coletivos, destacam-se obras como A poética do fundamento (1996), Formas da teoria (2002), A crítica literária e os críticos criadores no Brasil (2012), Literatura e cultura: do nacional ao transnacional (2013). Acrescentem-se os vários volumes coletivos que concebeu e organizou, entre os quais o marcante Palavras da crítica (1992), e se terá uma imagem de sua importante contribuição no âmbito das pesquisas especializadas e da produção bibliográfica na área dos estudos literários.

E da consagração ao ensino e à pesquisa na universidade resulta uma terceira frente em que atua, a da administração. Sua contribuição nessa esfera - que, de resto, desmente a crença usual na incompatibilidade entre a dedicação à pesquisa e o serviço administrativo - configura intenso compromisso com o fortalecimento institucional não só da UERJ e da UFF, mas do conjunto da área de Letras. Desse modo, o vemos no exercício de diversos cargos, nas duas universidades a que tem servido - chefe de departamento, diretor de unidade, coordenador de pós-graduação; na gestão de importantes associaçôes científicas, como a Associação Brasileira 
de Literatura Comparada (ABRALIC), de que foi presidente, e a Associação Nacional de Pós-Graduação e Pesquisa em Letras e Linguística (ANPOLL), cuja diretoria integrou; no assessoramento a agências de fomento à pesquisa, muito especialmente a Coordenação de Aperfeiçoamento de Pessoal de Nível Superior (CAPES), o Conselho Nacional de Desenvolvimento Científico e Tecnológico (CNPq) e a Fundação de Amparo à Pesquisa do Estado do Rio de Janeiro (FAPERJ). Em todos esses cargos e posiçôes, algumas constantes: capacidade de planejamento, clara visão técnica dos problemas, senso prático para resolvê-los, e, sobretudo, human skills na mediação de conflitos e na busca das convergências possíveis entre posiçóes polares.

O escritor, por fim, constitui uma quarta dimensão dessa personalidade múltipla e dinâmica. De certo modo, já mencionamos essa vertente do seu labor intelectual, com a referência feita a seus ensaios e livros, cujos textos sobressaem não só pelo rigor conceitual e correção acadêmica, mas também pela clareza, fluência e elegância de que são dotados, atributos que lhes conferem estatuto verdadeiramente literário. Acrescentemos, contudo - não sem alguma indiscrição -, que, no escritor, convivem o ensaísta, sua face pública e notória, e o poeta, este quase secreto, e praticamente só conhecido no círculo de seus amigos mais próximos, que, desse modo, pelo menos por enquanto, são os únicos em condiçóes de atestar-lhe o valor.

Professor, pesquisador, administrador, escritor: traços externos e funcionais, por certo, mas, nele, fecundados por intensa humanidade, sempre a assinalar-lhe gestos e atitudes, invariavelmente generosos, desprendidos, solidários.

Eis, então, Jobim, aliás, José Luís Jobim de Salles Fonseca. (UERJ/CNPq/FAPERJ) 